\title{
Determinasi Komposisi Campuran Lemak Babi dengan Sapi menggunakan Spektroskopi Inframerah Dekat dan Partial Least Square Regression
}

\author{
Rizki E. Agustin, ${ }^{1}$ Nur A. Wibowo, ${ }^{1}$ dan Ferdy S. Rondonuwu*1,2 \\ ${ }^{I}$ Fisika, Fakultas Sains Dan Matematika, Universitas Kristen Satya Wacana \\ Jl. Diponegoro 52-60, Salatiga 50711 \\ ${ }^{2}$ Pusat Studi Aplikasi NIR, Universitas Kristen Satya Wacana \\ Jl. Diponegoro 52-60, Salatiga 50711
}

Intisari

\begin{abstract}
Lemak merupakan salah satu komponen penting bagi tubuh manusia. Oleh sebab itu, lemak sering kali ditambahkan sebagai salah satu bahan dasar dalam kegiatan industri pangan maupun produk kosmetika. Kandungan lemak yang ada didalam produk diteliti oleh lembaga pemerintahan. Namun, kegiatan tersebut membutuhkan waktu yang lama dan tidak ramah lingkungan. Dalam tulisan ini, dilakukan teknik lain untuk menduga kandungan pada campuran lemak menggunakan spektroskopi inframerah dekat (Near Infrared Spectroscopy, NIRS) dan diikuti dengan perhitungan regresi kuadrat terkecil parsial (Partial Least Square Regression, PLSR). Pendugaan ini dilakukan dengan membuat sampel sebanyak 21 buah dengan persentase lemak babi terhadap lemak sapi(w/w), yaitu 0,00 sampai 1,00 dengan interval 0,05. Model kalibrasi ini dikembangkan menggunakan 11 sampel konsentrasi genap dan divalidasi menggunakan 10 sampel konsentrasi ganjil. Spektrum inframerah yang digunakan berada di kisaran 4.000-10.000 $\mathrm{cm}^{-1}$. Pra-perlakuan data meliputi smoothing, normalisasi, turunan pertama, dan turunan kedua digunakan untuk mengoptimalkan model prediksi PLSR-NIRS yang dikembangkan. Spektra turunan kedua digunakan untuk meningkatkan resolusi spektra sebelum dilakukan analisis PLS. Secara keseluruhan teknik NIRS dan PLSR berhasil menunjukkan persentase kandungan pada sampel campuran lemak babi dengan sapi.
\end{abstract}

\begin{abstract}
Fat is one of important elements for human's body. Therefore, fat is often added as one of main ingredients both in food industry activity and in cosmetic products. In this study, another technique was done to make an assumption about the content of fat by using Near Infrared Spectroscopy, NIRS and it was followed by Partial Least Square Regression, PLSR. This assumption was done by making 21 samples with the pork fat percentage toward the cow fat (w/w), which was $0,00,0,05$ until 1,00with the interval of 0,05 . This calibration model was developed using 11 samples of even concentrate and it was validated by using 10 samples of odd concentrate. The infra-red spectrum used in this study was around $4.000-10.000 \mathrm{~cm}^{-1}$. Prior data treatment covered smoothing, normalizing, the first, and the second derivative which were used to optimized the developed PLSR-NIRS prediction models. The second descending spectrum was used to increase the spectrum resolution before PLS analysis was done. Overall, the NIRS and PLSR techniques were sucessful in showing the percentage of the content in the mixted samples of pork and cow fat.
\end{abstract}

Keywords: Fat; NIRS; PLSR.

*Corresponding author: ferdy@ staff.uksw.edu

http://dx.doi.org/10.12962/j24604682.v15i3.4546

2460-4682 @Departemen Fisika, FSains-ITS

\section{PENDAHULUAN}

Lemak merupakan salah satu komponen penting bagi tubuh manusia. Secara umum lemak memenuhi fungsi dasar bagi manusia yaitu, sebagai pelindung organ tubuh, isolator dalam menjaga tubuh, sebagai pelarut vitamin A, D, E, K, dan penghasil energi sebesar $9 \mathrm{Kkal} / \mathrm{gram}$ saat dikonsumsi [1]. Lemak terdapat hampir di semua bahan pangan dengan kandungan yang berbeda-beda. Oleh sebab itu, lemak sering kali ditambahkan sebagai salah satu bahan dasar dalam kegiatan industri panganmaupun sebagian produk kosmetika [2]. Dalam industri pangan, lemak digunakan untuk memberikan efek rasa lezat, gurih, dan tekstur lembut [3], sedangkan dalam pembuatan produk kosmetika berfungsi sebagai penstabil emulsi krim dan lotion [2]. Oleh sebab itu, untuk mempertahankan kesehatan tubuh yang optimal sebaiknya lemak dikonsumsi 

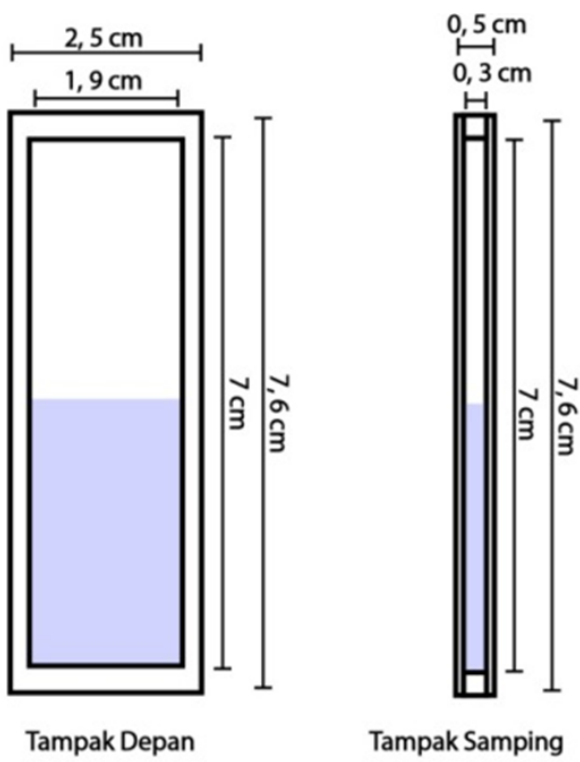

Gambar 1: Konstruksi wadah sampel.

sebanyak 25\% dari keseluruhan total energi yang digunakan dalam kesehariannya [4].

Segala bentuk penambahan lemak dalam produk pangan maupun kosmetika harus disesuaikan dengan kriteria standar penggunaan. Standar penggunaan ditiap negara biasanya mempunyai kriteria yang berbeda-beda. Sebagai contoh di Indonesia, produk-produk yang beredar dimasyarakat harus memenuhi kriteria standar penggunaan yang dikeluarkan oleh BPOM dan MUI. Akan tetapi, standar ini seringkali memicu permasalahan yang memunculkan isu tentang banyaknya produk yang bahan dasarnya tidak sesuai dengan yang tertera pada daftar komposisinya. Berkaitan dengan budaya keagamaan sebagian masyarakat Indonesia, banyaknya isuisu tersebut mengakibatkan kewaspadaaan yang tinggi [5]. Sebenarnya, sudah ada lembaga pemerintahan yang bertugas untuk memeriksa bahan dasar yang digunakan dalam pembuatan produk. Namun, kegiatan ini membutuhkan waktu yang lama dan cenderung mahal. Oleh sebab itu, dibutuhkan suatu metode untuk mengetahui kadar dari suatu bahan tertentu sehingga kriteria standar penggunaan dapat sesuai dengan kebutuhan masyarakat.

Dibutuhkan suatu metode untuk menentukan kadar bahan tertentu yang digunakan dalam pembuatan produk pangan dan kosmetika secara tepat, cepat, ramah lingkungan, dan tidak merusak bahan itu sendiri. Metode yang berpotensi dan sedang banyak digunakan, yaitu spektroskopi inframerah dekat (Near Infrared Spectroscopy, NIRS). NIRS telah banyak digunakan dalam bidang industri maupun penelitian ilmiah karena dapat menggambarkan struktur energi dari senyawa-senyawa yang ada di dalam produk pangan secara cepat dan tidak mahal [6]. Fourier Transform Near Infrared (FT-NIR) dapat juga digunakan untuk mengukur konten iodine value (IV) dan asam lemak bebas (Free Fatty Acid, FFA) pada lemak hewani dalam lingkungan produksi biodiesel secara cepat dan tepat [7]. Namun, spektra hasil pengukuran spektrometer NIR biasanya menghasilkan gambaran yang sangat mirip dan terlihat saling tertumpuk satu dengan lainnya sehingga tidak memungkinkan apabila dilakukan evaluasi hanya dengan melihat grafik panjang gelombangnya saja [8]. Jadi, dibutuhkan analisis lain untuk mengatasi masalah tersebut. Salah satu metode yang sering digunakan, yaitu analisis statistik multivariat regresi kuadrat terkecil parsial (Partial Least Square Regression, PLSR). Oleh sebab itu, NIRS merupakan salah satu teknik yang mampu memberikan analisis secara cepat dan tepat.

PLSR merupakan salah satu metode untuk menganalisis informasi yang tersembunyi dalam data spektrum. Metode ini digunakan untuk memperkirakan respon dari prediksi yang jumlahnya sangat banyak sehingga struktur sistematik liniernya mempunyai korelasi yang baik [9]. Barlocco dkk. [10] dalam penelitiannya untuk memprediksi lemak intramaskular (intramuscular fat, IMF), moisture dan kekuatan geser Warner-Bratzler pada otot babi menggunakan metode NIR yang dikombinasikan dengan multivariat PLS menyatakan bahwa NIR mempunyai potensi yang baik dalam memprediksi moisture dan IMF untuk sampel utuh tanpa perlakuan khusus. Djssica Tatiana Raspe and Camila da Silva [11] dalam penelitiannya untuk menentukkan persentase FFA menyatakan bahwa spektroskopi FT-NIR yang digabungkan dengan kalibrasi multivariat PLS menghasilkan korelasi yang baik sehingga teknik ini sangat menjanjikan untuk memantau reaksi esterifikasi pada produksi biodiesel. Jadi, dapat dikatakan bahwa PLSR merupakan metode yang cocok sebagai analisis lanjutan dari data-data yang diukur oleh NIRS.

Dari banyaknya penelitian tentang lemak hewani, penelitian untuk mengidentifikasi konsentrasi campuran lemak babi dengan sapi murni tanpa menggunakan campuran bahan kimia lain belum banyak dilakukan. Oleh sebab itu, perlu dikembangkan suatu metode yang dapat dilakukan dengan cepat, ramah lingkungan, dan tidak merusak bahan itu sendiri. Paper ini bertujuan untuk membangun model prediksi kandungan lemak babi pada campuran babi dengan sapi menggunakan NIRS dan teknik analisis PLSR yang diharapkan dapat digunakan untuk menduga komponen kimia dari berbagai macam konsentrasi campuran lemak.

\section{METODOLOGI}

\section{Preparasi Sampel}

Sejumlah 1.000 gram jaringan lemak digunakan dalam pembuatan sampel untuk masing-masing lemak babi dan sapi. Preparasi sampel dilakukan dalam lima tahapan. Tahap pertama, yaitu pemisahan lemak dari daging yang berada dekat dengan dinding perut. Tahap kedua adalah pemanasan lemak sampai menjadi cair, selanjutnya dilakukan penyaringan supaya tidak ada lagi sisa-sisa kotoran hasil pemanasan yang dilakukan. Tahap ketiga adalah pembuatan wadah dan dudukan sampel. Konstruksi wadah sampel ditunjukkan pada Gambar 1. Bahan yang digunakan untuk membuat wadah sampel, yaitu 2 buah kaca mikroskop dan 1 buah penyangga. Penyangga diposisikan berada diantara kedua buah kaca 


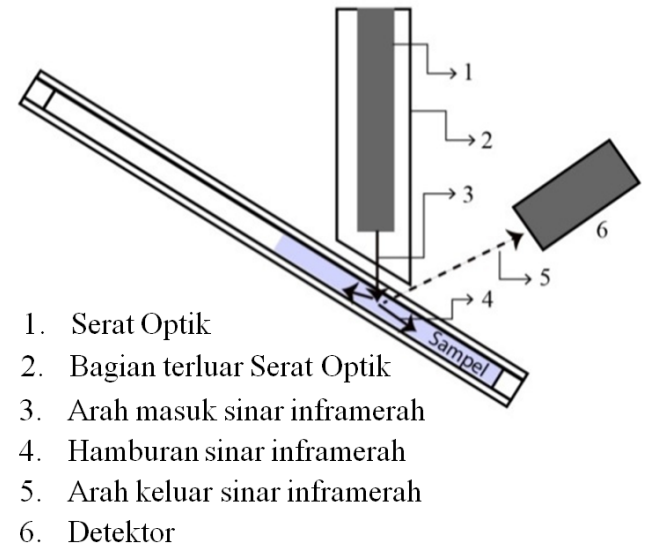

Gambar 2: Skema pemindaian sampel.

mikroskop. Tampak depan menggambarkan area yang diukur, sedangkan tampak samping memberikan gambaran ketebalan sampel yang digunakan. Tahap keempat adalah membuat sampel sebanyak 21 buah dengan persentase lemak babi terhadap lemak sapi (w/w), yaitu 0,00 sampai 1,00 dengan interval 0,05 . Pada tahap ini campuran lemak terlebih dahulu ditempatkan ke dalam botol vial. Selanjutnya, didiamkan selama \pm 1 jam pada ruangan yang mempunyai suhu $24^{\circ} \mathrm{C}$ sampai menjadi padat. Tahap kelima adalah memasukkan sampel yang telah padat ke dalam wadah sampel. Sampel yang telah siap ditempatkan di atas dudukan sampel yang kemudian dilakukan pemindaian sampel.

\section{Pengukuran spektrum}

Skema pemindaian sampel ditunjukkan dalam Gambar 2. Lemak dipindai dengan menggunakan perangkat NIRFlex N500 Solid merk BUCHI yang dihubungkan dengan perangkat kabel serat optik. Pemindaian dilakukan pada bilangan gelombang 4.000-10.000 $\mathrm{cm}^{-1}$. Sinar inframerah dekat yang datang mengenai permukaan wadah sampel berinteraksi dengan sampel kemudian dihamburkan. Hamburan tersebut membawa informasi dari sampel yang selanjutnya diteruskan ke detektor. Permukaan sampel yang digunakan bersifat halus sehingga menghasilkan mode reflektansi.

\section{Pra-perlakuan data}

Pra-perlakuan data dilakukan untuk mendapatkan hasil analisis terbaik dari penelitian. Pra-perlakuan data yang dilakukan adalah (a). smoothing, (b). normalisasi, (c). turunan pertama ( $1^{\text {st }}$ derivative), dan (d). turunan kedua $\left(2^{n d}\right.$ derivative). Smoothing berfungsi untuk menghilangkan derau frekuensi tinggi pada tiap spektrum, normalisasi berfungsi untuk menghilangkan pengaruh perbedaan ukuran partikel sampel, turunan pertama berfungsi untuk memperbaiki baseline yang tidak overlapping, dan turunan kedua berfungsi untuk memberikan resolusi yang lebih jelas pada spektrum. Smoothing dilakukan dengan metode Savitszky-Golay polinomial orde 3 dengan pembingkaian sebesar 21. Teknik ini digunakan karena derau pada spektrum dapat terminimalisir de-

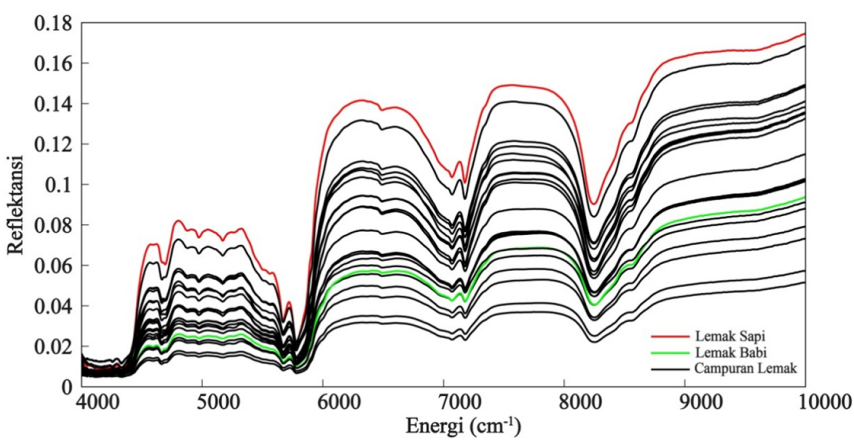

Gambar 3: Spektra lemak sapi (merah), lemak babi (hijau), dan campuran lemak babi dengan sapi (hitam).

ngan baik sehingga dihasilkan analisis spektrum yang maksimal. Normalisasi dengan mengabaikan baseline yang fluktuatif dilakukan dengan membuat nilai reflektansi minimum pada energi $4200 \mathrm{~cm}^{-1}$ menjadi nol dan maksimum pada $9000 \mathrm{~cm}^{-1}$ menjadi satu. Selanjutnya, dilakukan operasi turunan pertama dan kedua.

\section{Analisis data}

Untuk mengembangkan model kalibrasi kuantitatif digunakan metode PLSR. Spektra turunan kedua digunakan untuk meningkatkan resolusi spektra sebelum dilakukan analisis PLS. Metode ini diawali dengan mencari nilai dari prediksi jumlah kesalahan kuadrat (Predicted Residual Error Sum Of Square, PRESS) dengan menggunakan berbagai komponen $(\mathrm{N})$ [12]. Nilai PRESS dapat dihitung menggunakan persamaan PRESS $=\sum_{i=1}^{N}\left(y_{i}-\hat{y}_{i,-i}\right)^{2}$, dengan $\mathrm{N}$ adalah komponen PLS yang digunakan, $y_{i}$ adalah data acuan, dan $\hat{y}_{i,-i}$ merupakan prediksi data ke-i pada perhitungan koefisien regresi. Model kalibrasi ini dikembangkan menggunakan 11 dari 21 sampel konsentrasi genap (kelompok data kalibrasi) dan divalidasi menggunakan 10 sampel konsentrasi ganjil (kelompok data validasi). Parameter-parameter yang memberikan nilai PRESS minimum dari model yang dibangun melalui perhitungan PLSR dipilih sebagai model terbaik dalam memprediksi konsentrasi lemak [13]. Semua proses analisis dilakukan dengan menggunakan bantuan Matlab R2017B dan software lainnya yang terkait.

\section{HASIL DAN DISKUSI/PEMBAHASAN}

Spektrum reflektansi dari keseluruhan sampel disajikan pada Gambar 3. Pola spektra hasil pemindaian menunjukkan bentuk yang sama dengan baseline yang sedikit berbeda. Hal ini disebabkan adanya perbedaan komponen antara lemak babi dengan sapi [14]. Selain itu, seberapa mudahnya lemak mengental juga berpengaruh terhadap tingkat reflektansi yang dihasilkan [15]. Sebagai contoh reflektansi lemak babi pada Gambar 4(a) lebih rendah daripada lemak sapi maka dapat dikatakan bahwa lemak babi lebih sulit mengental dibandingkan dengan lemak sapi. Untuk mengoreksi baseline spektrum, dilakukanlah proses pra-perlakuan data. 


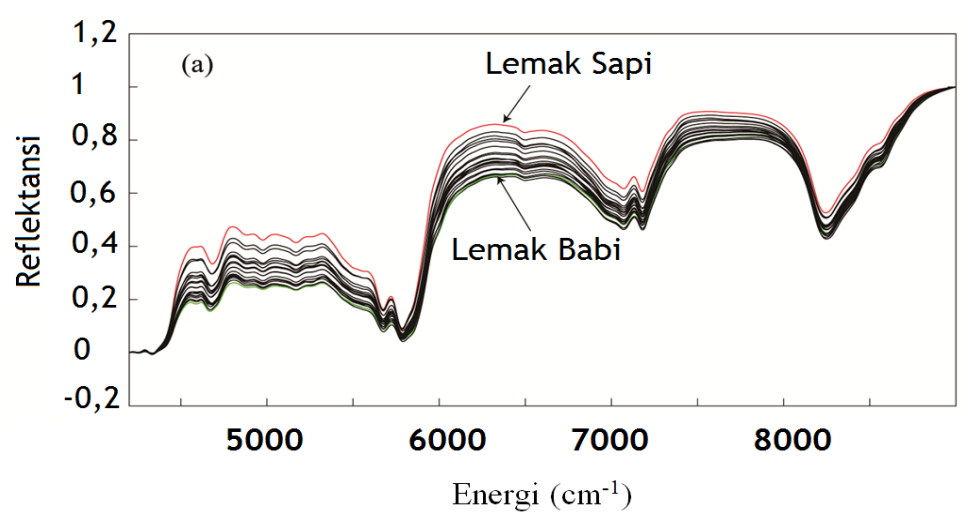

(a)

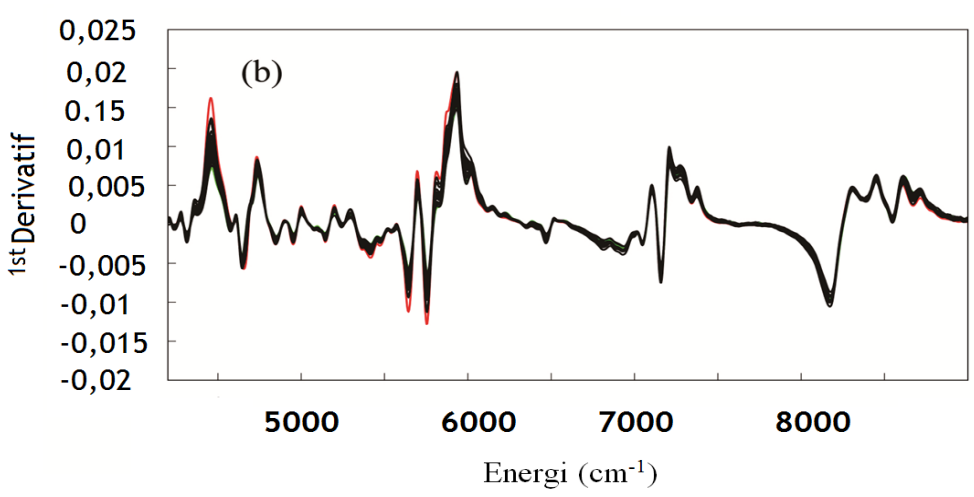

(b)

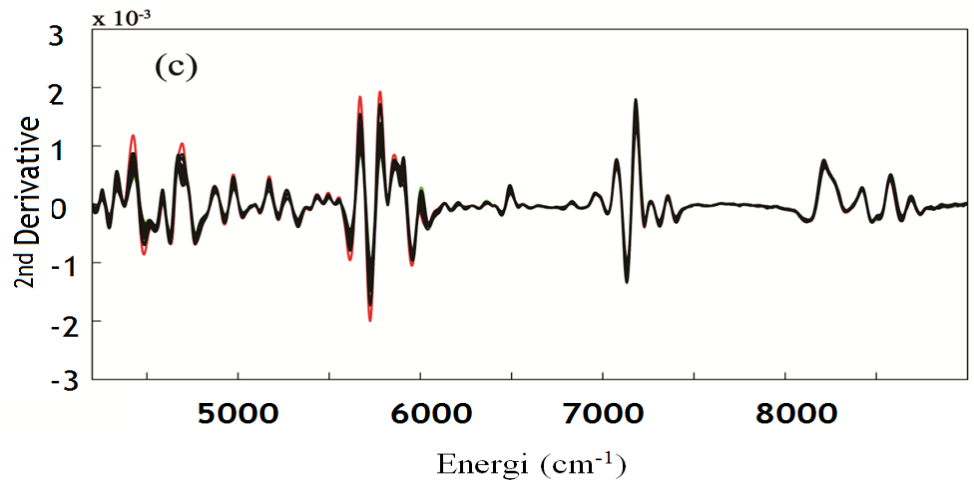

(c)

Gambar 4: Spektra hasil pra-perlakuan data: (a). normalisasi, (b). turunan pertama, (c). turunan kedua.

Dalam spektrum reflektansi, semua serapan dimulai dengan nilai reflektansi rendah. Jadi, lembah yang muncul menunjukkan adanya penyerapan molekul yang terjadi. Li et al [16] melaporkan daerah kalibrasi optimal sebagian besar pita serapan pada penentuan IV minyak nabati diwilayah NIR adalah $\mathrm{CH}$ overtone dan pita kombinasi. Daerah 5500-6200 $\mathrm{cm}^{-1}$ terdiri dari first overtone $\mathrm{CH}, 8200-8500 \mathrm{~cm}^{-1}$ second overtone $\mathrm{CH}$, dan 4000-4500 merupakan pita kombinasi $\mathrm{CH}_{2}$. Penyerapan pada $5900-8475 \mathrm{~cm}^{-1}$ disebabkan oleh ikatan ganda $(-\mathrm{CH}=\mathrm{CH}-)$ yang kuat, sedangkan pita kombinasi ditemukan di daerah 4566-4675 $\mathrm{cm}^{-1}$. Peter et al. [7] melaporkan daerah spektrum NIR untuk melihat kandungan FFA lemak hewan dan campurannya berada di daerah $6900 \mathrm{~cm}^{-1}$ merupakan first overtone dari ikatan $\mathrm{O}-\mathrm{H}$, sedangkan second overtone C-Hstretching berada didaerah $7600-9000 \mathrm{~cm}^{-1}$. Lengkey et al [17] melaporkan daerah reflektansi NIR pada biji jarak pagar yang terdiri atas ikatan $\mathrm{O}-\mathrm{H}$ menyerap pada daerah 5100-6800 $\mathrm{cm}^{-1}$, kadar lemak terdiri atas ikatan $(\mathrm{CH}$, $\left.\mathrm{CH}_{2}, \mathrm{CH}_{3}\right)$; CHstretching berada pada 4305, 4329, 4546, $5666,7168,8230 \mathrm{~cm}^{-1}, \mathrm{CH}_{2}$ di daerah $5600-7000 \mathrm{~cm}^{-1}$, dan $\mathrm{CH}_{3}$ di daerah $5900 \mathrm{~cm}^{-1}$, sedangkan kandungan lemak berada di daerah 4304-4329 $\mathrm{cm}^{-1}$. Kemudian dilaporkan bahwa daerah spektra ini seragam untuk berbagai macam minyak dan lemak [16]. Pada penelitian ini kandungan air yang terdiri atas ikatan O-H menyerap pada energi 5792 dan $7064 \mathrm{~cm}^{-1}$ yang diindikasikan oleh lembah yang cukup tajam pada spektrum 


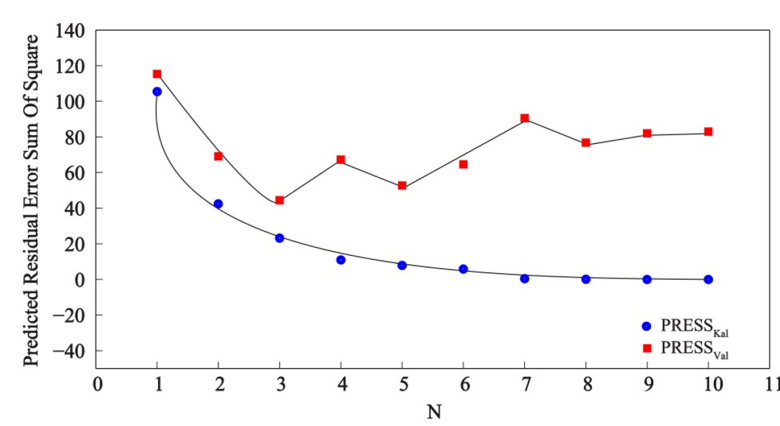

Gambar 5: Predicted residual error sum of square turunan kedua.

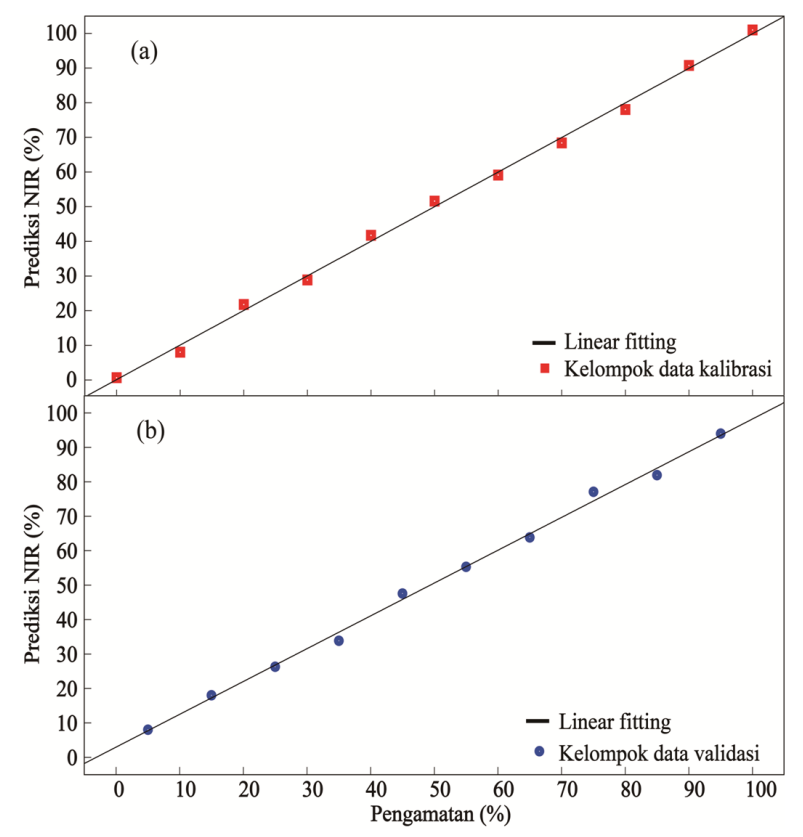

Gambar 6: Grafik hubungan antara: (a) kelompok data kalibrasi dalam plot regresi dan (b) kelompok data validasi dalam plot regresi.

reflektansi NIR. Pita kombinasi $\mathrm{CH}$ berada didaerah 4000$4352 \mathrm{~cm}^{-1}$, first overtone $\mathrm{CH}$ di daerah $5840-6488 \mathrm{~cm}^{-1}$, dan second overtone $\mathrm{CH}$ di daerah $7164-9000 \mathrm{~cm}^{-1}$.

Hasil pra-perlakuan data ditunjukkan oleh Gambar 4 (a)(c). Pada proses ini derau yang terjadi pada Gambar 3 telah dihilangkan dengan melakukan smoothing seperti yang terlihat pada Gambar 4. Untuk membandingkan nilai reflektansi spektrum, diperlukan transformasi data menggunakan normalisasi sehingga data awal yang berada pada rentang 0,007-0,170 pada Gambar 3 menjadi 0-1 seperti yang terlihat pada Gambar 4(a). Selanjutnya, dilakukan transformasi lain dengan turunan pertama seperti yang terlihat pada Gambar 4(b). Pada proses turunan pertama, baseline spektrum yang tidak overlapping bertransformasi menjadi overlapping. Turunan kedua diterapkan untuk menaikkan daya pisah spektrum sehingga puncak-puncak yang tadinya lebar menjadi lebih sempit. Dengan demikian posisi dan tinggi puncak dapat terbedakan secara lebih jelas.
Selanjutnya dilakukan analisis lanjutan, analisis lanjutan yang digunakan adalah PLSR. PLSR digunakan untuk menganalisis spektrum yang saling tumpang tindih sehingga informasi yang tersembunyi didalamnya dapat diketahui. Proses ini diawali dengan mencari nilai PRESS dari tanpa pra-perlakuan data, normalisasi, turunan pertama, sampai dengan turunan kedua. Atas dasar nilai PRESS, daerah yang bersesuaian dengan pita kombinasi, first overtone dan second overtone dari ikatan $\mathrm{CH}$ digunakan untuk menghasilkan model kalibrasi dalam analisis PLSR. Perhitungan daerah $8104-8800 \mathrm{~cm}^{-1}$ ditemukan sebagai penghasil kalibrasi yang baik untuk melihat konsentrasi campuran lemak dengan kesalahan prediktif minimum.

PRESS ditentukkan dalam berbagai kondisi, yaitu tanpa pra-perlakuan data, normalisasi, turunan pertama dan turunan kedua. Masing-masing kondisi spektrum ditentukanlah PRESS berdasarkan PLSR untuk berbagai N seperti yang ditunjukkan pada Tabel I. Pada Tabel I terlihat bahwa PLSR terkecil dicapai pada kondisi spektrum turunan kedua dengan $\mathrm{N}=3$. Meskipun nilai PRESS terus turun pada data kalibrasi namun pada data validasi nilai PRESS akan meningkat lagi sampai $\mathrm{N}$ tertentu seperti yang ditunjukkan pada Gambar 5.

Perbandingan antara prediksi NIR dan data sebenarnya ditunjukkan pada Gambar 6. Gambar 6(a) menampilkan perbandingan antara prediksi NIR dan riil untuk kelompok data kalibrasi, sedangkan Gambar 6(b) adalah perbandingan antara prediksi NIR dan data sebenarnya. Disini prediksi NIR menggunakan data kalibrasi pada (a) untuk menduga data-data riil pada (b). Jadi, model yang digunakan untuk memprediksi kandungan lemak babi pada kelompok data validasi diambil dari persamaan kalibrasi kelompok data yang lain. Hasilnya menunjukkan bahwa prediksi NIR dan nilai sebenarnya dari konsentrasi lemak babi sangat dekat. Hal ini ditunjukkan dengan koefisien determinasi $\left(\mathrm{R}^{2}\right)$ yang dihasilkan mendekati 1 , yaitu 0,98 . Artinya, hasil prediksi NIR mirip dengan hasil riil dari konsentrasi lemak babi. Jadi, model kalibrasi dengan $\mathrm{N}=3$ pada bentangan $8104-8800 \mathrm{~cm}^{-1}$ cukup akurat dalam menentukkan konsentrasi lemak babi pada sampel campuran lemak babi dengan lemak sapi.

\section{SIMPULAN}

Determinasi kandungan pada campuran lemak babi dengan sapi dapat dilakukan dengan baik menggunakan NIRS yang dikombinasikan dengan perhitungan PLSR. Analisis ini berhasil menunjukkan perbedaan komponen kimia dari berbagai macam konsentrasi campuran lemak babi dengan sapi. Pendugaan kandungan lemak terbaik didapatkan pada bentangan energi $8104-8800 \mathrm{~cm}^{-1}$. Jumlah $\mathrm{N}$ sangat kritikal untuk menentukkan akurasi daricampuran lemak. Dalam penelitian ini $\mathrm{N}=3$ dari spektra turunan kedua memberikan hasil yang lebih baik dibandingkan dengan spektra pengukuran langsung maupun turunan pertama. Metode ini dapat menjadi alternatif untuk menentukkan kandungan lemak dengan cepat, ramah lingkungan, dan tidak merusak bahan itu sendiri. 
TABEL I: Nilai PRESS tanpa pra-perlakuan dan pra-perlakuan data.

\begin{tabular}{|c|c|c|c|c|c|c|c|c|}
\hline \multirow[t]{2}{*}{$\mathrm{N}$} & \multicolumn{2}{|c|}{ Tanpa Pra-perlakuan Data } & \multicolumn{2}{|c|}{ Normalisasi } & \multicolumn{2}{|c|}{ Turunan Pertama } & \multicolumn{2}{|c|}{ Turunan Kedua } \\
\hline & PRESS $_{K a l}$ & PRESS $_{V a l}$ & PRESS $_{K a l}$ & PRESS $_{V a l}$ & PRESS $_{K a l}$ & PRESS $_{V a l}$ & PRESS $_{K a l}$ & PRESS $_{V a l}$ \\
\hline 1 & 1.990 & 3.360 & 4.300 & 10.400 & 127,58 & 618,56 & 105,49 & 115,31 \\
\hline 2 & 1.630 & 2.490 & 131,51 & 598,71 & 60.15 & 349,81 & 42,43 & 69,10 \\
\hline 3 & 388,48 & 688.30 & 26,76 & 150,04 & 19,99 & 67,07 & 23,16 & 44,43 \\
\hline 4 & 28.23 & 1.080 & 16,80 & 119,67 & 15,61 & 62,08 & 10,90 & 67,27 \\
\hline 5 & 19,86 & 1.070 & 10,52 & 126,68 & 11,29 & 62,22 & 7,83 & 52,70 \\
\hline 6 & 6.94 & 762,51 & 3,81 & 207,91 & 7,98 & 76,31 & 5,82 & 64,60 \\
\hline 7 & 2,87 & 818,27 & 0,89 & 200,77 & 4,17 & 77,21 & 0,46 & 90,58 \\
\hline 8 & 0,41 & 777,72 & 0,01 & 222,34 & 0,07 & 89,32 & 0,09 & 76,76 \\
\hline 9 & 0,0093 & 776,38 & 0,000369 & 222,95 & 0,0097 & 85,45 & 0,0021 & 82,04 \\
\hline 10 & $1,55 \mathrm{E}-23$ & 781,49 & $8,23 \mathrm{E}-23$ & 223,07 & $5,16 \mathrm{E}-26$ & 87,31 & $2,39 \mathrm{E}-26$ & 82,97 \\
\hline
\end{tabular}

[1] O.R. Fenema, "Food Chemistry", Third Edition. USA: Marcell Dekker, 1996.

[2] S. Ramlah, "Karakteristik Mutu Dan Efek Penambahan Polifenol Pada Hand Body Lotion Berbasis Lemak Kakao Terhadap Kulit”, Balai Besar Ind. Has. Perkeb., vol. 12, hlm. 29-39, Des 2017.

[3] D.A.R. Sartika, "Pengaruh Asam Lemak Jenuh, Tidak Jenuh dan Asam Lemak Trans terhadap Kesehatan", J. Kesehat. Masy. Nas., vol. 2, hlm. 154-160, Feb 2008.

[4] N.K. Wiardani, P.P.S. Sugiani, dan N.M.Y. Gumala, "Konsumsi lemak total, lemak jenuh, dan kolesterol sebagai faktor risiko sindroma metabolik pada masyarakat perkotaan di Denpasar", J. GIZI Klin. Indones., vol. 7, no.3, hlm. 121-128, Mar 2011.

[5] M. Ali, "Konsep Makanan Halal Dalam Tinjauan Syariah dan Tanggung Jawab Produk Atas Produsen Industri Halal", Ahkam, vol. XVI, Jul 2016.

[6] H. Huang, H. Yu, H. Xu, dan Y. Ying, ”Near infrared spectroscopy for on/in-line monitoring of quality in foods and beverages: A review”, J. Food Eng., vol. 87, pp. 303-313, 2008.

[7] P. Adewale, O. Mba, M.-J. Dumont, M. Ngadi, dan R. Cocciardi, "Determination Of The Iodine Value and The Free Fatty Acid Content of Waste Animal Fat Blends Using FT-NIR", Vib. Spectrosc., vol. 72, pp. 72-78, 2014.

[8] R. A. Rozandy, I. Santoso, dan S. A. Putri, ”Analisis Variabel - Variabel Yang Mempengaruhi Tingkat Adopsi Teknologi Dengan Metode Partial Least Square (Studi Kasus Pada Sentra Industri Tahu Desa Sendang, Kec. Banyakan, Kediri),” J. Ind., vol. 1 No 3, hlm. 147-158, 2013.

[9] A.T.E. Prasetya, N.A. Wibowo, dan F.S. Rondonuwu, "Determination of total quality of black tea fanning grade using nearinfrared spectroscopy", J. Phys. Conf. Ser., vol. 1097, no. 1, pp. $1-7,2018$.

[10] N. Barlocco, A. Vadell, F. Ballesteros, G. Galietta, dan D. Coz- zolino, "Predicting Intramuscular Fat, Moisture And WarnerBratzler Shear Force In Pork Muscle Using Near Infrared Reflectance Spectroscopy", Anim. Sci., vol. 82, pp. 111-116, 2006.

[11] D.T. Raspe dan C. da Silva, "Determination of Free Fatty Acid by FT-NIR Spectroscopy in Esterification Reaction for Biodiesel Production", J. Energy, vol. 2013, pp. 1-5, 2013.

[12] D.M. Haaland dan E.V. Thomas, "Partial Least-Squares Methods for Spectral Analyses. 1. Relation to Other Quantitative Calibration Methods and the Extraction of Qualitative Information", Anal. Chem., vol. 60, no. 11, pp. 1193-1202, Jun 1988.

[13] M.H. Kutner, C.J. Nachtsheim, J. Neter, dan W. Li, "Applied Linear Statistical Models", Fifth Edition, Illinois, Irwin, 1990.

[14] S. Hermanto, A. Muawanah, dan R. Harahap, "Profil Karakteristik Lemak Hewani (Ayam, Sapid an Babi) Hasil Analisa FTIR dan GCMS", State Islam. Univ., vol. 1, no. 3, hlm. 102-109, 2008.

[15] C. Vichasilp dan O. Poungchompu, "Feasibility of Detecting Pork Adulteration in Halal Meatballs Using near Infrared Spectroscopy (NIR)", CMUJ NS Spec. Issue Food Appl. Biosci., vol. 13, no. 1, pp. 497-507, 2014.

[16] H. Li, V. de Voort, dan A. Ismail, "Rapid Determination of cis and trans Content, Iodine Value, and Saponification Number of Edible Oils by Fourier Transform Near-Infrared Spectroscopy", J. Am. Oil Chem. Soc., vol. 76, pp. 491-497, Apr 1999.

[17] L.C.E.C. Lengkey, I.W. Budiastra, K.B. Seminar, dan B.S. Purwoko, "Model Pendugaan Kandungan Air, Lemak Dan Asam Lemak Bebas Pada Tiga Provenan Biji Jarak Pagar (Jatropha Curcas L.) Menggunakan Spektroskopi Inframerah Dekat Dengan Metode Partial Least Square (Pls)", J. Littri, vol. 19, no. 4, hlm. 203-211, Des 2103. 